Research Article

\title{
Cerebroprotective activity of 3-benzylxanthine derivative - compound Ale-15, in conditions of bilateral common carotid arteries ligation (ischemic stroke)
}

\author{
Sergey V. Levich ${ }^{1}$, Katherine V. Aleksandrova ${ }^{1}$, Igor F. Belenichev ${ }^{2}$, Alexander S. Shkoda ${ }^{1}$
}

\author{
${ }^{1}$ Department of Biochemistry \\ and Laboratory Diagnostic, \\ ${ }^{2}$ Department of Pharmacology, \\ Zaporozhye State Medical \\ University, Zaporozhye, 69035, \\ Ukraine
}

Received: 4 October 2013

Revised: 7 October 2013

Accepted: 27 October 2013

*Correspondence to:

Dr. Sergey V. Levich,

Email: rshlevas@gmail.com

(C) 2013 Levich SV et al. This is an open-access article distributed under the terms of the Creative Commons Attribution Non-Commercial License, which permits unrestricted non-commercial use, distribution, and reproduction in any medium, provided the original work is properly cited.

\begin{abstract}
Background: Acute ischemic stroke is a leading cause of mortality, morbidity, long-term disability in industrialized countries. One of main parts of it pathogenesis is production of reactive oxygen species. The accumulation of them in neurons results in lipid peroxidation, protein oxidation, DNA damage, and finally cell death. Thereby the search of novel drugs, that have antioxidant action and can be used to complex treatment of cerebral strokes is reasonable. It is known, that xanthine derivatives exhibit a broad spectrum of biological activity, including antioxidant. So that, the goal of this research was to study in vivo neuroprotective action of water-soluble derivative of 3-benzylxanthine morpholin-4-ium 3-benzylxanthinyl-8-methylthioacetate (Ale-15 compound) in comparison with neuroprotector-antioxidant - Mexidol.

Methods: Experimental part was done on white Wistar rats of both sexes of 220$260 \mathrm{~g}$ weight. For assessment of neuroprotective action of compound we used a model of global incomplete cerebral ischemia, that was reproduced by bilateral common carotid arteries ligation.

Results: It was studied an acute toxicity of Ale-15 compound, it influence on survival of laboratory animals, on progression of neuralgic deficit, on the content of adenylic nucleotides, on criteria of energy metabolism, on the activity of antioxidant enzymes and on oxidative modification of protein. Results of study showed, that injection of Ale-15 compound to animals with ischemic stroke intragastrically during 4 days positively reduced death rate and quantity of animals with serious neurologic symptoms. The main parts of Ale-15 cerebroprotective mechanism are antioxidant and anti-ischemic actions.

Conclusions: The performed study revealed significant cerebroprotective features of Ale-15 compound in conditions of experimental cerebrovascular accident.
\end{abstract}

Keywords: Xanthine, Antioxidant activity, Cerebroprotective action, Ischemic stroke

\section{INTRODUCTION}

In past years the prevalence growth of cardio-vascular diseases, that includes also cerebrovascular accidents (CVA), was noted. ${ }^{1}$ Ischemic brain injuries are followed by serious neuralgic disorders, such as cognitive, motor, verbal impairment and other functions of central nervous system $(\mathrm{CNS}){ }^{2}$ Acute ischemic stroke is a leading cause of mortality, morbidity, long-term disability in industrialized countries, and involves a complex array of processes involving multiple biological systems which collectively determine the susceptibility to and outcome from the ischemic event. ${ }^{3,4}$
That is why the search for methods for pharmacological correction of these disorders and medications, that decrease degree of neurodegeneration in case of cerebral ischemia, is an essential issue of modern medicinal science.

Oxidative stress, defined as the accumulation of reactive oxygen species (ROS) plays a pivotal role in neurodegeneration associated with ischemia, trauma, and other neurodegenerative diseases. ${ }^{5-9}$ The accumulation of ROS in neurons results in lipid peroxidation, protein oxidation, DNA damage, and finally cell death. ${ }^{5-9}$

Nowadays an active search for new cerebroprotectors is being carried out among compounds, that affect the compensatory shunt of ATP synthesis in conditions of 
cerebral ischemia, that modulate glutamate- and GABAergic systems, regulate activity of Ca-channels and system of nitrogen oxide, and also among antioxidants, neuropeptides, expression inhibitors of proinflammatory cytokines and antagonists of IL-1 $\beta$-receptors. ${ }^{2,10}$

Strong interrelation between disorder of energetic and plastic metabolism, their effect on course and prognosis of disease are often ignored while making treatment regimens; the main pathogenic treatment is deemed to be hemodynamic recovery. Recently a lot of attention is concentrated on disorder of energy metabolism and on the abilities of its correction. A lot of scientists think, that metabolic support, that is realised not only in acute period of stroke, but also in post-acute, is a powerful preventive factor in respect to repeated strokes, disability and death of patients. ${ }^{11}$ Thereby the addition of drugs, that have energotropic, antioxidant, anti-ischemic and nootropic actions to complex treatment of cerebral strokes is reasonable. ${ }^{6,8,9,12}$

Substituted xanthine derivatives are an important class of pharmacologically active compounds that are known to exhibit various pharmacological properties including antioxidant. ${ }^{13,14}$ Earlier we mentioned about the synthesis of Ale-15 compound - (morpholin-4-ium 3benzylxanthinyl-8-methylthioacetate) (Figure 1), that shows high antioxidant qualities in vitro. ${ }^{15}$

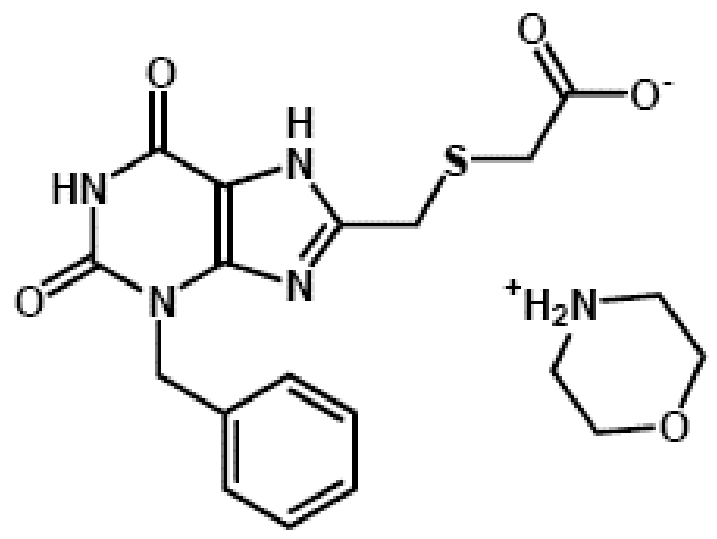

Figure 1: Morpholin-4-ium 3-benzylxanthinyl-8methylthioacetate - Ale-15.

The goal of this research was to study in vivo neuroprotective action of Ale-15 compound in conditions of bilateral common carotid arteries ligation (ischemic stroke) and in comparison with pharmacological standard of neuroprotector-antioxidant - Mexidol. ${ }^{16,17}$

\section{METHODS}

\section{Animals}

Experimental part was done on white Wistar rats of both sexes of 220-260 g weight. All animals were on standard food ration of vivarium, with natural alteration of day and night. Rats were received from nursery of Institute of
Pharmacology and Toxicology of Ukraine. All experimental procedures and operative interventions were done in accordance with WMA Statement on Animal Use in Biomedical Research.

\section{Acute toxicity}

Determination of acute toxicity of derivative xanthine was carried out by Kerber method in Loit modification, using Sidorov classification. ${ }^{18,19}$ For determination of median lethal dose $\left(\mathrm{LD}_{50}\right)$ of Ale-15 compound under investigation it was injected intragastrically as water solution with the help of metal catheter one time to 5 groups (each route of entry) of laboratory animals, 6 animal units in each group. Several doses of Ale-15 were injected, including dose, which does not lead to death of any animal and dose, that leads to death of all the animals in group. After injection of Ale-15 the animals, that survived, were examined during two weeks.

\section{Stroke model}

For assessment of neuroprotective action of compound we used a model of global incomplete cerebral ischemia, that is the most adequate in terms of clinical implications of ischemic stroke. ${ }^{20}$ This model was reproduced by bilateral common carotid arteries ligation that was performed under ethaminal-natrium anesthesia $(40 \mathrm{mg} /$ $\mathrm{kg}$ ), with implication of surgical approach by means of separation of carotid arteries and single-step silk deligation. ${ }^{20}$ We took $1 / 20 \mathrm{LD}_{50}$ as the relatively curative dose. The compound Ale-15 under research was injected once a day during the whole experiment at a dose of 50 $\mathrm{mg} / \mathrm{kg}$ intragastrically with the help of metal catheter; Mexidol was injected according to the same schedule at a dose of $250 \mathrm{mg} / \mathrm{kg}$ intragastrically. The intact group was presented by pseudo-operated animals, that underwent the separation of carotid arteries under ethaminal-natrium anesthesia $(40 \mathrm{mg} / \mathrm{kg})$, with implication of surgical approach without deligation.

\section{Biochemical analysis}

Material: For assessment of severity of ischemic injury of cerebral tissues and pharmacocorrection efficiency we performed biochemical arterial blood analysis. For investigation of long-term results of pharmacocorrection we took brain from experimental animals the fourth day after the operation. We used cerebral cortex frontal lobes for biochemical investigation. For biochemical investigation cerebral tissues were homogenized in cold in salt isotonic solution $(0.15 \mathrm{M} \mathrm{KCl})$ at the temperature of $+4^{\circ} \mathrm{C}$ with the help of glass homogenizer, in ratio tissue - salt solution 1:10. After that, we separated cytosolic fraction $(15000 \mathrm{~g})$ by means of differential centrifugation. Extract, deprived of proteins, was obtained precise weight of homogenate of cerebral tissue in $0.6 \mathrm{M}$ solution of $\mathrm{HClO}_{4}$ with further neutralization with $5.0 \mathrm{M}$ solution of potassium carbonate. ${ }^{21}$ 
State of antioxidant system: The state of antioxidant system was assessed by the activity of superoxide dismutase (SOD), catalase, glutathione peroxidase (GPx), by index of oxidative modification of protein in cerebral tissue. Determination of SOD activity was carried out by method, that is specified by Chevary and coauthors. ${ }^{22}$ SOD activity was stated by c.u./mg of protein/min. Catalase activity was determined spectrophotometrically. ${ }^{23}$ Catalase activity was stated by $\mathrm{mkat} / \mathrm{mg}$ of protein/min. GPx activity was determined by method. ${ }^{24}$ The activity of GPx was stated by $\mu \mathrm{mol} / \mathrm{GSH} / \mathrm{mg}$ of protein $/ \mathrm{min}$. The index of oxidative protein modification in cerebral tissues was determined with the help of method of B. Halliwell. ${ }^{25,26}$ For aldehyde phenylhydrazones (APH) the spector of absorption is detected at wave length of $274 \mathrm{~nm}$, and for carboxyl phenylhydrazones (CPH) the wave length was $363 \mathrm{~nm}$.

The state of energy metabolism: The state of energy metabolism was determined by the level of the most important intermediates - ATP, ADP, AMP, lactate, pyruvate and malate. Ischemic injury of cerebral tissues was determined by hyperenzymemia of creatine phosphokinaseBB. The activity of creatine phosphokinase-BB was determined after separation on the DEAE Sephadex A-50 with optical test according to Warburg. ${ }^{27}$ The activity of creatine phosphokinase-BB was stated by $\mu \mathrm{m} / \mathrm{l} / \mathrm{h}$. The quantity of malate was detected according to method of Hohorst. ${ }^{28}$ The creation of renovated form of $\mathrm{NAD}^{+}$is equal to the quantity of oxidized malate, the growth of which is indicated at $340 \mathrm{~nm}$. Adenylic nucleotides were determined by thin layer chromatography. ${ }^{21}$ The content of pyruvate was determined by method of Zoh-Lompreht. ${ }^{21}$ The quantity of pyruvate used in reaction ia equal to the quantity of $\mathrm{NAD}^{+}$with its decrease at $340 \mathrm{~nm}$. The content of lactate was determined by the method of Hohorst. ${ }^{28}$ The creation of new form of $\mathrm{NAD}^{+}$is equal to the quantity of oxidized lactate, the quantity growth of which is indicated at $340 \mathrm{~nm}$.
Neurologic impairment: The neurologic impairment was determined by the scale stroke-index C.P. McGrow. ${ }^{29}$

Statistical analysis: The statistic data processing was carried out with the help of software for statistic data processing STATISTICA® for Windows 6.0 (StatSoft Inc. AXXR712D833214FAN5). ${ }^{30}$ The data is presented by sample mean \pm standard error of the mean. The control of distribution normalcy was done in accordance with Shapiro-Wilk criteria. The fidelity of differences between experimental groups was estimated with the help of Student's t-test and of Whitney-Mann test.

\section{RESULTS}

\section{Acute toxicity}

Intragastric injection of Ale-15 in a dose of $1050 \mathrm{mg} / \mathrm{kg}$ resulted in $100 \%$ mortality of the animals during the day, a dose of $850 \mathrm{mg} / \mathrm{kg}$ did not cause death. Injection of intermediate doses - 900, 950 and $1000 \mathrm{mg} / \mathrm{kg}$ caused death of $16.7 \%, 50 \%$ or $83.3 \%$ of animals respectively (table 1). The obtained experimental data showed that the test compound didn't show significant toxicity, and its $\mathrm{LD}_{50}$ was $950 \pm 20 \mathrm{mg} / \mathrm{kg}$.

\section{Influence on survival and progression of neuralgic deficit}

Double-sided common carotid arteries ligation caused serious neurological changes in animals organisms, e.g. paralysis, paresis, ptosis, with maximum demonstration on the fourth day. So, the average score of uncured group of animals for this period corresponded to serious degree of neuralgic symptoms according to C.P. McGraw scale (Table 2).

Table 1: Results of acute toxicity test in rats following intragastric injection of compound Ale-15 after 2 weeks of observation.

\begin{tabular}{|llllll|}
\hline Dose, $\mathrm{mg} / \mathrm{kg}$ & 850 & 900 & 950 & 1000 & 1050 \\
\hline Proportion of survived rats on the $14^{\text {th }}$ day, $\%$ & 100 & 83.3 & 50 & 16.6 & 0 \\
\hline
\end{tabular}

Table 2: Influence of Ale-15 on survival and progression of neuralgic deficit of animal in different periods on time after CVA on the $4^{\text {th }}$ day.

\begin{tabular}{|llll|}
\hline Animals group & $\begin{array}{l}\text { Quantity of rats with } \\
\text { serious symptoms, \% }\end{array}$ & $\begin{array}{l}\text { Average score acc. } \\
\text { to C.P. McGrow } \\
\text { scale }\end{array}$ & $\begin{array}{l}\text { Proportion of operated/ } \\
\text { survived rats on the } 4^{\text {th }} \\
\text { day, \% }\end{array}$ \\
\hline Sham surgery animals & 0 & $2.00 \pm 0.60$ & $(5 / 5) 100$ \\
\hline Animals with CVA & 100 & $19.1 \pm 7.64$ & $(15 / 5) 33$ \\
\hline Animals with CVA+Ale-15 & 76.9 & $10.8 \pm 4.32 *$ & $(15 / 13) 86.7 *$ \\
\hline Animals with CVA+Mexidol & 87.5 & $15.7 \pm 3.2 *$ & $(15 / 8) 53 *$ \\
\hline
\end{tabular}

Remark: $*$ - $\mathrm{p} \leq 0.05$ in relation to control 
On the $4^{\text {th }}$ day in control group $33 \%$ of animals survived. Injection of Ale-15 compound to animals created evident cerebroprotective effect. So on the $4^{\text {th }}$ day of experiment the average score of this group by C.P. McGraw scale was 10.8 , and mortality decreased in comparison with control. However, $76.9 \%$ of animals showed serious neurologic deficit. Mexidol gave way to Ale-15 in terms of neuroprotective action.

Influence on the content of adenylic nucleotides and on criteria of energy metabolism
Biochemical investigations showed that double-sided common carotid arteries ligation led to typical ischemic disorders, such as deficit of macroergic phosphates, incoordination in the Krebs cycle, activity of anaerobic glycolysis and development of oxidative stress.

Injection of Ale-15 compound led to increasing of ATP level, malate level, pyruvate level, and decreasing in lactate content in comparison with control. In action of Mexidol we noted similar, but less evident effect in relation to criteria of bioenergetics (Tables 3 and 4).

Table 3: Influence of Ale-15 on the content of adenylic nucleotides in brain and on the activity of creatine phosphokinase-BB in animals blood serum on the $4^{\text {th }}$ day after CVA.

\begin{tabular}{|c|c|c|c|c|}
\hline Animals group & $\begin{array}{l}\text { ATP mcM/g } \\
\text { of tissue }\end{array}$ & $\begin{array}{l}\text { ADP } \\
m c M / g \text { of tissue }\end{array}$ & $\begin{array}{l}\text { AMP } \\
m c M / g \text { of tissue }\end{array}$ & $\begin{array}{l}\text { Creatine } \\
\text { phosphokinase-BB } \\
m M / l / h o u r\end{array}$ \\
\hline Sham surgery animals & $2,01 \pm 0,12$ & $0,53 \pm 0,005$ & $0,12 \pm 0,003$ & $0,04 \pm 0,003$ \\
\hline Animals with CVA & $1,07 \pm 0,07$ & $0,24 \pm 0,003$ & $0,27 \pm 0,002$ & $0,17 \pm 0,005$ \\
\hline Animals with CVA+Ale-15 & $1,71 \pm 0,11 *$ & $0,46 \pm 0,003 *$ & $0,12 \pm 0,008^{*}$ & $0,067 \pm 0,003 *$ \\
\hline Animals with CVA+Mexidol & $1,33 \pm 0,12 *$ & $0,44 \pm 0,005^{*}$ & $0,15 \pm 0,011^{*}$ & $0,093 \pm 0,005^{*}$ \\
\hline
\end{tabular}

Remark: * $-\mathrm{p} \leq 0.05$ in relation to control

Table 4: Influence of Ale-15 compound on criteria of energy metabolism in brain on the $4^{\text {th }}$ day after CVA.

\begin{tabular}{|c|c|c|c|}
\hline Animals group & $\begin{array}{l}\text { Pyruvate } \\
m c M / g \text { of tissue }\end{array}$ & $\begin{array}{l}\text { Lactate } \\
m c M / g \text { of tissue }\end{array}$ & $\begin{array}{l}\text { Malate } \\
m c M / g \text { of tissue }\end{array}$ \\
\hline Sham surgery animals & $0,51 \pm 0,06$ & $2,7 \pm 0,02$ & $0,26 \pm 0,03$ \\
\hline Animals with CVA & $0,22 \pm 0,02$ & $9,2 \pm 0,07$ & $0,11 \pm 0,01$ \\
\hline Animals with CVA+Ale-15 & $0,50 \pm 0,02 *$ & $3,5 \pm 0,07 *$ & $0,44 \pm 0,03 *$ \\
\hline Animals with CVA+Mexidol & $0,37 \pm 0,04 *$ & $4,9 \pm 0,03 *$ & $0,26 \pm 0,02 *$ \\
\hline
\end{tabular}

Remark: * $-\mathrm{p} \leq 0.05$ in relation to control

\section{Influence on the activity of antioxidant enzymes and oxidative modification of protein}

During the simulation of CVA we discovered increase of APH and KPH products of oxidative protein modification in cerebral tissues of rats on the $4^{\text {th }}$ day (table 5). Injection of Mexidol led to decrease of neurotoxic products of oxidative modification of protein (OMP), that are APH and $\mathrm{KPH}$. Ale-15 compound showed powerful antioxidant action in acute period of cerebral ischemia via oxidative protein modification suppression. It was illustrated by positively low level of APH and KPH in cerebral tissues of rats, that took course of Ale-15, in comparison with animals, that were not cured. In brains of animals, that underwent treatment with Ale-15, the increased activity of key antioxidant enzymes and the decrease of hyperenzymemia of creatine phosphokinase-BB was noted (Tables 3 and 6).
Table 5: Influence of Ale-15 compound on oxidative modification of protein in brain on the $4^{\text {th }}$ day after CVA.

\begin{tabular}{|lll|}
\hline \multirow{2}{*}{ Animals group } & \multicolumn{2}{l|}{ OPM products, c.u./g of protein } \\
\cline { 2 - 3 } & APH $(270 \mathrm{~nm})$ & KPH $(363 \mathrm{~nm})$ \\
\hline Sham surgery animals & $6,2+0,42$ & $7,5 \pm 0,40$ \\
\hline Animals with CVA & $19,7 \pm 3,77$ & $31,6 \pm 2,11$ \\
\hline Animals with CVA+Ale-15 & $8,1 \pm 0,37 * 1$ & $12,6 \pm 0,87 * 1$ \\
\hline Animals with CVA+Mexidol & $12,7 \pm 1,0^{*}$ & $18,7 \pm 1,87^{*}$ \\
\hline
\end{tabular}

Remark: * - $\mathrm{p} \leq 0.05$ in relation to control

${ }^{1}-\mathrm{p} \leq 0.05$ in relation to animals group, that took Mexidol 
Table 6: Influence of Ale-15 on the activity of antioxidant enzymes in brain on the $4^{\text {th }}$ day after CVA.

\begin{tabular}{|llll|}
\hline $\begin{array}{l}\text { Animals } \\
\text { group }\end{array}$ & $\begin{array}{l}\text { SOD, } \\
\text { c.u./mg of } \\
\text { protein/min }\end{array}$ & $\begin{array}{l}\text { Catalase, } \\
\text { moAb/mg } \\
\text { of protein/ } \\
\text { min }\end{array}$ & $\begin{array}{l}\text { GPx, } \\
\text { mcM/mg of } \\
\text { protein/min }\end{array}$ \\
\hline $\begin{array}{l}\text { Sham surgery } \\
\text { animals }\end{array}$ & $284,1 \pm 13,4$ & $15,5 \pm 1,35$ & $68,3 \pm 3,5$ \\
\hline $\begin{array}{l}\text { Animals with } \\
\text { CVA }\end{array}$ & $117,1 \pm 5,8$ & $8,7 \pm 0,5$ & $41,2 \pm 3,4$ \\
\hline $\begin{array}{l}\text { Animals with } \\
\text { CVA+Ale-15 }\end{array}$ & $270,2 \pm 12,3 *$ & $14,0 \pm 0,70^{*}$ & $63,7 \pm 3,1^{*}$ \\
\hline $\begin{array}{l}\text { Animals with } \\
\text { CVA+Mexidol }\end{array}$ & $187,3 \pm 9,7 *$ & $11,7 \pm 0,75^{*}$ & $47,5 \pm 7,7$ \\
\hline
\end{tabular}

Remark: $*-p \leq 0.05$ in relation to control

\section{DISCUSSION}

The performed investigation revealed significant cerebroprotective features of Ale-15 compound in conditions of experimental CVA. Injection of Ale-15 compound to animals with CVA in dose of $50 \mathrm{mg} / \mathrm{kg} / \mathrm{day}$ intragastrically during 4 days reduced death rate and quantity of animals with serious neurologic symptoms (decrease by C.P. McGrow scale).

The main parts of Ale-15 cerebroprotective mechanism are anti-ischemic activity (intensification of aerobic reactions of ATP creation) and its antioxidant action (suppressing of nerve tissue oxidative protein modification), that was discovered and described for the first time in researches in vitro. ${ }^{15}$

Injection of Ale-15 compound led to increasing of ATP synthesis by means of activation of aerobic oxidation cycle, that is indicated by increasing of malate level, decreasing of lactate content, that is the evidence of decreasing lactate-acidosis in nerve tissue and increasing pyruvate level in comparison with control. It should be noted, that Ale-15 caused the increasing level of ATP on the background of decreasing level of AMP, that is prooxidant and thrombocyte aggregation inductor. Evidently the compound Ale-15 has positive impact on metabolism of adenylic nucleotides, intensifying AMP utilization, and thus leads to further retardation of xanthine oxidase reaction of ROS.

The most considerable part in antioxidant action of Ale15 in CVA conditions is protection of neurons protein molecules. Known, that one of main parts of cerebral ischemia pathogenesis is production of ROS by bioenergetic and neurochemical systems of brain. ${ }^{3,6-9,31}$ ROS surplus in conditions of antioxidant lack leads to oxidative modification of lipids, proteins, nucleic acids. Oxidative modification of protein receptor fragments, ion channels, synaptic structures of neuron leads to disorder of generation, creation and nerve impulse conduction, interrupts synaptic transmission and, as a result, leads to deterioration of cognitive-mnestic brain functions. ${ }^{9,31,32}$ It is also known, that under the influence of ROS begins the activation of redox-sensitive genes expression, one of them is necessary for protection of cells from toxic effects of oxidative stress, and others initiate apoptotic neuronal cell death in case of surplus of ROS. ${ }^{3,6-9,31,33}$ Nowadays oxidative stress and its part - oxidative proteins modification is one of the most considerable mechanisms of neuro destruction.

Injection of Ale-15 led to the increasing of activity of key antioxidant enzymes. These enzymes are SOD, catalase and GPx, that control main neuron antioxidant safety layers. It is obvious, that Ale-15 compound under investigation lowered the level of oxidative destruction not only of protein part of antioxidant enzymes, but also of non-protein active center. That is proved by our investigation in vitro by the example of SOD. ${ }^{15}$

Such antioxidant action of compound Ale-15 is very important and is decisive in determination of total mechanism of its neuroprotective action. It means that Ale-15 neuroprotective mechanism is characteristic for the most of secondary neuroprotectors with antioxidant mechanisms.

It should also be noted, that as a result of suppressing of oxidative protein modification of nerve tissue and rise of its resistance to ischemia, the stabilization of neurons membrane also occurred on the background of Ale-15 usage. The evidence of this is the positive decrease of creatine phosphokinase-BB hyperenzymemia of the animals, that was not cured, and of animals, that underwent the course of Mexidol.

The performed investigation revealed that by the strength of neuroprotective action Ale-15 compound exceeds pharmacological standard of neuroprotective and antioxidant action - Mexidol.

Funding: No funding sources

Conflict of interest: None declared

Ethical approval: Approval taken

\section{REFERENCES}

1. WHO. Disease and Injury Country Estimates. Geneva. 2009.

2. Gusev EL, Skvortsova VI. Brain ischemia. 1st ed. Moscow, M: Meditsina Publishers: 2001:326.

3. Alexandrova ML and Bochev PG. Oxidative stress in stroke. In: Ali Qureshi G, Hassan Parves S, eds. Oxidative stress and neurodegenerative disorders. 1st ed. Amsterdam, London: Elsevier; 2007:313368.

4. McColl BW, Allan SM and Rothwell NJ. Systemic infection inflammation and acute ishemic stroke. Neurosci 2009;158:1049-1061. 
5. Coyle JT and Puttfarcken P. Oxidative stress, glutamate and neurodegenerative disorders. Science 1993;262:689-695.

6. Satoh T, Enokido Y, Kubo K, Yamada M and Hatanaka H. Oxygen toxicity induces apoptosis in neuronal cells. Cell Mol Neurobiol 1999;18:649666.

7. Satoh $\mathrm{T}$ and Lipton SA. Redox regulation of neuronal survival by electrophilic compounds. Trends Neurosci 2007;30:37-45.

8. Satoh T, Okamoto S, Cui J, Watanabe Y, Furuta K, Suzuki $M$ et al. Activation of the Keap1/Nrf2 pathway for neuroprotection by electrophilic phase II inducers. Proc Natl Acad Sci USA 2006;103:768773.

9. Satoh T and Izumi M. Neuroprotective effects of phenylenediamine derivatives independent of an antioxidant pathway in neuronal HT22 cells. Neurosci Let 2007;418:102-105.

10. Chiueh CC. Neurobiology of $\mathrm{NO}$ and $\mathrm{OH}$ : basic research and clinical relevance. Ann N Y Acad Sci 1994;738:279-281.

11. Scott B and Auroma O. Oxidative stress, oxidants and antioxidants. Exp Physiol 1999;8:291-295.

12. Ullegaddi R, Powers HJ and Gariballa SE. Antioxidant supplementation enhances antioxidant capacity and mitigates oxidative damage following acute ischemic stroke. Eur $J$ Clin Nutr 2005;59:1367-1373.

13. Bhat VB and Madyastha KM. Antioxidant and radical scavenging properties of 8-oxoderivatives of xanthine drugs pentoxifylline and lisofylline. Biochem and Biophys Res Commun 2001;288:1212-1217.

14. Barth A, Kaiser N, Leffler U, Sourgens H and Klinger W. Influence of the xanthine derivative denbufylline and the antiinflammatory agent nabumetone on microsomal free radical production and lipid peroxidation in rat liver. Exp Toxic Pathol 1994;46:483-489.

15. Aleksandrova KV, Belenichev IF, Shkoda AS, Buhtiyarova NV, Levich SV. Pat. UA 54957 U. In. Cl. C 07 D 473/00. Water-soluble salts of 3benzylxanthinyl-8-methylthioacetic acid, exhibiting antioxidant action. № u201007741; Pub. date. 25.11.2010. Bul. № 22 .

16. Gnezdilova A, Ganshina $\mathrm{T}$ and Mirzoyan $\mathrm{R}$. Cerebrovascular effects of mexidol in conditions of separate and combined vascular pathology of brain and heart. Eur Neuropsychopharmacology 2011; Suppl 2:S124.

17. Tilekeyeva UM and Sitina LI. Stress-protective effect of mexidol on different levels of natural altitudes. Eur Neuropsychopharmacology 2005; Suppl 2:S209.

18. Loit AO and Savchenikov MF. Prophylactic toxicology: a guide for toxicologists experimenters. 1st ed. Irkutsk, I: Irkutskiy University Publishers; 1996: 76-77.

19. Sidorov KK. Toxicology of new industrial chemicals. 1st ed. Moscow, M: Meditsina Publishers; 1973: 47.

20. Carmichael ST. Rodent models of focal stroke: size, mechanism and purpose. NeuroRX 2005;2(3):396409.

21. Prohorova MI. Modern methods of biochemical investigations (lipid and energy metabolism. 1st ed. Leningrad, L: Leningradskiy University Publishers; 1982: 272.

22. Chevari S, Chaba I and Seker I. Role of superoxide dismutase in cellular oxidative processes and method of its determination in biological materials. Lab Delo 1985;11:678-81.

23. Korolyuk MA. The method of determining the activity of catalase. Lab Delo 1988;1:16-19.

24. Belenichev IF and Maksimenko SF. Changes in the activity of glutathione peroxidase in patients with occlusive vascular lesions of the optic nerve. J Ophtalmol 1996;3:150-153.

25. Halliwell B., Gutteridze JM. Free radicals in biology and medicine. 1st ed. Oxford, O: Clarendon Press; 1985: 346

26. Halliwell B. Molecular biology of free radicals in human diseases. 1st ed. St. Lucia, London, L: OICA; 1999: 410.

27. Chance B. Optical method. Annu Rev Biophys Biophys Chern 1991;20:1-28.

28. Hohorst HJ. Enzymatic method of the lactate concentration in blood. In: Bergmeyer HU, ed. Methods of Enzymatic Analysis. 1st ed. Weinheim, Bazel, B: Verl Chemie; 1970: 1425.

29. McGrow CP. Experimental cerebral infarction effects of pentobarbital in mongolian gerbils. Arch Neurol 1977;34(6):334-336.

30. Zaycev VM, Liflyandskiy VG and Marinkin VI. Applied Medical Statistics: Textbook. 1st ed. Saint Petersburg, SP: Foliant Publishers; 2006: 432.

31. Ozkul A, Akyol A, Yenisey C, Arpaci E, Kiylioglu $\mathrm{N}$ and Tataroglu C. Oxidative stress in acute ischemic stroke. J Clin Neurosci 2007;14:10621066.

32. Liu TH, Beckman JS, Freeman BA, Hogan EL and Hsu CY. Polyhethylene glycol-conjugated superoxidedismutase and catalase reduce ischemic brain injury. Am J Physiol 1989;256:589-593.

33. Manzanero $\mathrm{S}$, Santro $\mathrm{T}$ and Arumugam TV. Neuronal oxidative stress in acute ischemic stroke: Sources and contribution to cell injury. Neurochem Int 2013;62(5):712-718.

doi:10.5455/2319-2003.ijbcp20131207

Cite this article as: Levich SV, Aleksandrova KV, Belenichev IF, Shkoda AS. Cerebroprotective activity of 3-benzylxanthine derivative - compound Ale-15, in conditions of bilateral common carotid arteries ligation (ischemic stroke). Int J Basic Clin Pharmacol 2013;2:705-10. 